\title{
KAJIAN BAHAYA ERUPSI DAN LONGSOR PADA LEMBAH ANTAR GUNUNGAPI MERAPI-MERBABU JAWA TENGAH
}

\author{
(A STUDY ON THE HAZARD OF ERUPTION AND LANDSLIDE \\ IN INTERVOLCANIC BASIN OF MERAPI-MERBABU CENTRAL JAVA)
}

\author{
Nurhadi, Arif Ashari, dan Suparmini
}

\author{
Fakultas Ilmu Sosial Universitas Negeri Yogyakarta \\ J1. Colombo No. 1 Yogyakarta \\ email: geonurhadi@gmail.com
}

\begin{abstract}
Abstrak
Penelitian ini bertujuan untuk: (1) mengkaji tingkat bahaya erupsi dan longsor, dan (2) membuat peta persebaran keruangan bahaya di wilayah lembah antargunungapi MerapiMerbabu, Provinsi Jawa Tengah. Metode yang digunakan adalah eksploratif-survei, dengan pendekatan kewilayahan. Populasi dalam penelitian ini adalah seluruh lembah antargunungapi Merapi-Merbabu yang berada pada sebagian wilayah Kecamatan Sawangan, Kabupaten Magelang, dan Kecamatan Selo, Kabupaten Boyolali. Sampel pengamatan ditentukan dengan teknik purposive sampling yaitu pada setiap satuan medan. Pengumpulan data dilakukan dengan observasi, interpretasi citra penginderaan jauh, studi pustaka, dan dokumentasi. Analisis yang digunakan adalah analisis SIG, analisis pengharkatan, didukung dengan analisis deskriptif. Hasil penelitian menunjukkan bahaya erupsi gunungapi bervariasi antara tingkat sedang hingga tinggi. Bahaya sedang terdapat di wilayah Gunungapi Merbabu, sedangkan bahaya tinggi berada di wilayah Gunungapi Merapi. Bahaya tinggi terutama dipengaruhi oleh nilai tinggi dari jarak dari kepundan aktif Gunungapi Merapi dan kemiringan lereng. Bahaya longsor bervarasi antara sangat rendah hingga sedang. Bahaya sangat rendah dan rendah terdapat di wilayah Gunungapi Merapi sedangkan bahaya sedang terdapat di wilayah Gunungapi Merbabu. Bahaya sedang terutama dipengaruhi oleh nilai tinggi dari kemiringan lereng, tekstur tanah, ketebalan solum tanah, dan kerapatan vegetasi.
\end{abstract}

Kata kunci: bencana, bahaya, pengelolaan kebencanaan.

\begin{abstract}
This study aimed to: (1) assess the eruption and landslide hazard, and (2) create a map of the spatial distribution of hazard in intervolcanic basin of the Merapi-Merbabu, Central Java Province. The method employs in this research was exploratory surveys, with regional complex approach. The population in this study were all landscape phenomena between intervolcanic basin of Merapi-Merbabu, located in parts of sub-district Sawangan, Magelang District, and sub-district Selo, Boyolali District. Sample was determined by observation of purposive sampling technique that at each terrain unit. Data collecting was carried out with observation, interpretation of remote sensing imagery, literature review, and documentation. The analysis used GIS analysis, scoring analysis, supported by descriptive analysis. The results showed the hazard of volcanic eruption varies between moderate to high. Moderate hazard exist in the area of Merbabu Volcano, while high hazard exist in the area of Merapi Volcano. High hazard mainly affected by high level of distance from active crater of Merapi Volcano and slope. The landslide hazard varies between very low to moderate. Very low and low hazard exist in the area of Merapi Volcano, while moderate hazard exist in the area of Merbabu Volcano. Moderate hazard mainly affected by high level of slope, soil texture, soil depth, and vegetation density.
\end{abstract}

Keywords: disaster, hazard, disaster management 


\section{PENDAHULUAN}

Karakteristik geologis, geomorfologis, dan klimatis Kepulauan Indonesia yang berada pada pertemuan tiga lempeng tektonik besar yang aktif dan saling bertumbukan, didukung oleh variasi konfigurasi relief, dengan iklim tropis basah menyebabkan tingginya potensi bencana alam. Berbagai peristiwa bencana yang terjadi telah menimbulkan kerugian harta benda dan korban jiwa dalam jumlah tidak sedikit. Keadaan ini menunjukkan bahwa risiko bencana alam di Indonesia masih cukup tinggi. Selain karena banyaknya jenis bahaya yang mengancam, risiko bencana juga disebabkan karena semakin meningkatnya jumlah manusia yang rentan terhadap ancaman bencana serta masih rendahnya kemampuan masyarakat dalam menghadapi bencana (Sudibyakto, 2007; Lavigne, 2010). Bahaya merupakan faktor risiko yang relatif tidak dapat diubah sehingga perlu adanya informasi yang akurat mengenai tingkat bahaya melalui pemantauan, analisis, dan pemetaan tingkat bahaya pada suatu wilayah.

Sebagaimana diamanatkan pada UU Nomor 24 Tahun 2007 tentang penanggulangan bencana dan PP Nomor 21 tahun 2008 tentang penyelenggaraan penanggulangan bencana, risiko bencana dapat dikurangi dengan melakukan tindakan manajemen kebencanaan. Mengingat bahwa ancaman bahaya di Indonesia sangat banyak dan risiko bencana yang masih tergolong tinggi, manajemen kebencanaan perlu segera diterapkan. Untuk mendukung upaya tersebut terlebih dahulu diketahui daerah-daerah yang menghadapi ancaman bahaya tinggi, oleh karenanya pemetaan tingkat bahaya menjadi sangat penting untuk dilakukan dalam upaya memberikan informasi dasar bagi kegiatan pengelolaan kebencanaan.

Lembah antargunungapi MerapiMerbabu secara administratif termasuk dalam wilayah Kecamatan Sawangan Kabupaten Magelang dan Kecamatan Selo Kabupaten Boyolali. Wilayah ini secara geomorfologis terletak di antara dua vulkan berusia kuarter yang termasuk dalam kategori vulkan aktif tipe A dan B (Van Padang, 1983; Van Bemmelen, 1970). Vulkan Merapi merupakan vulkan yang aktif, termasuk salah satu dari 23 vulkan tipe A di Pulau Jawa, bahkan disebut-sebut sebagai vulkan paling aktif selama holosen (Sudradjat, 2010; Verstappen, 2000; Verstappen, 2013). Aktivitas vulkanik Merapi menimbulkan ancaman bagi masyarakat yang bertempat tinggal di wilayah lembah antargunungapi Merapi-Merbabu, terlebih permukiman masyarakat umumnya berada pada jarak kurang dari $10 \mathrm{~km}$ dari pusat erupsi. Vulkan Merbabu tergolong vulkan yang tidak begitu aktif. Namun demikian, pengaruh iklim yang kuat dalam waktu lama pelapukan batuan hasil erupsi masa lampau pada Vulkan Merbabu berlangsung cepat. Kondisi 
ini menyebabkan timbulnya bahaya gerakan massa terutama dalam bentuk longsor, aliran, dan nendatan.

Potensi bahaya erupsi gunungapi dan longsor yang terdapat pada lembah antargunungapi Merapi-Merbabu menunjukkan perlunya dilakukan tindakan manajemen kebencanaan dalam upaya mengurangi risiko bencana. Dalam pengelolaan kebencanaan, identifikasi tingkat bahaya memberikan bahan pertimbangan untuk pengambilan berbagai kebijakan yang berhubungan dengan penanganan bencana. Paradigma manajemen kebencanaan saat ini yang lebih cenderung menekankan aspek pra bencana juga memerlukan penilaian risiko bencana yang diawali dengan analisis bahaya. Dengan kajian risiko dan kemampuan dalam menghadapi bencana, termasuk di dalamnya kajian bahaya dan kerawanan, selanjutnya dapat disusun arahan manajemen kebencanaan khususnya pada tahap mitigasi bencana dan kesiapsiagaan (Flanagan et al., 2011; Eiser et al., 2012; Kaku and Held, 2013). Tujuan dari penelitian ini adalah untuk mengkaji tingkat bahaya erupsi dan longsor pada lembah antargunungapi Merapi-Merbabu dan membuat peta persebaran keruangan bahaya di wilayah lembah antargunungapi MerapiMerbabu.

\section{METODE PENELITIAN}

Penelitian ini menggunakan metode eksploratif-surveidengan pendekatan geografi yaitu pendekatan kewilayahan. Penelitian ini merujuk kepada disiplin ilmu geomorfologi dengan satuan medan sebagai unit analisis. Alat yang digunakan dalam penelitian ini terdiri dari alat pengukuran lapangan dan alat laboratorium. Alat pengukuran lapangan meliputi GPS, kompas geologi, kamera digital, abney level, serta alat tulis dan checklist. Alat laboratorium meliputi seperangkat komputer dengan perangkat lunak ArcGIS, plotter, dan printer. Bahan yang digunakan dalam penelitian ini meliputi Peta Geologi, Peta Rupabumi Indonesia, dan Citra Landsat Jawa Tengah.

Populasi dalam penelitian ini adalah seluruh lembah antar gunungapi MerapiMerbabu. Pengambilan sampel dilakukan dengan teknik purposive sampling pada setiap satuan medan. Satuan medan digunakan sebagai unit sampling karena medan sebagai suatu kesatuan fisik permukaan berpengaruh terhadap bahaya erupsi dan gerakan massa. Kondisi medan yang berbeda satu sama lain tentunya memiliki tingkat bahaya dan risiko yang berbeda. Data dikumpulkan melalui observasi, dokumentasi, interpretasi citra penginderaan jauh, dan studi pustaka. Analisis yang digunakan antara lain analisis bahaya secara deskriptif dengan pengharkatan, analisis SIG dengan teknik overlay dan buffering, dan analisis keruangan. Analisis bahaya diawali dengan melakukan pengharkatan tingkat bahaya di daerah penelitian (Tabel 1 dan Tabel 2). 
Tabel 1. Kriteria dan Harkat Masing-Masing Variabel Bahaya Erupsi Gunungapi

\begin{tabular}{|c|c|c|}
\hline No & Kriteria dan Harkat & Skor \\
\hline A & Unit Bentuk Lahan & \\
\hline 1 & Kepundan dan kerucut gunungapi & 5 \\
\hline 2 & Lereng Gunungapi & 4 \\
\hline 3 & Kaki Gunungapi & 3 \\
\hline 4 & Dataran kaki Gunungapi & 2 \\
\hline 5 & Dataran Fluvial Gunungapi & 1 \\
\hline B & Unit Relief & \\
\hline 1 & Datar-berombak lemah & 5 \\
\hline 2 & Berombak & 4 \\
\hline 3 & Bergelombang & 3 \\
\hline 4 & Berbukit & 2 \\
\hline 5 & Bergunung & 1 \\
\hline $\mathrm{C}$ & Jarak dari Alur Sungai & \\
\hline 1 & $<100$ meter & 5 \\
\hline 2 & $100-500$ meter & 4 \\
\hline 3 & 500 meter- 1 kilometer & 3 \\
\hline 4 & 1-2 kilometer & 2 \\
\hline 5 & $>2$ kilometer & 1 \\
\hline $\mathrm{D}$ & Kelas Lereng \& Kriteria & \\
\hline 1 & V $(>51 \%)$ - Sangat curam & 5 \\
\hline & IV (21-50\%) - Curam & 4 \\
\hline & III (15-20\%) - Agak Curam & 3 \\
\hline 4 & II (8-14\%) - Miring & 2 \\
\hline 5 & I $(<8 \%)$ - Datar-landai & 1 \\
\hline $\mathrm{E}$ & Jarak dari Kepundan & \\
\hline 1 & $<1$ kilometer & 5 \\
\hline & 1-5 kilometer & 4 \\
\hline 3 & 5-10 kilometer & 3 \\
\hline 4 & 10-20 kilometer & 2 \\
\hline 5 & $>20$ kilometer & 1 \\
\hline & Kerapatan Vegetasi & \\
\hline 1 & Lahan terbuka $(<10 \%)$ & 5 \\
\hline & Kerapatan sangat rendah $(<25 \%)$ & 4 \\
\hline 3 & Kerapatan rendah $(25-50 \%)$ & 3 \\
\hline & Kerapatan sedang $(50-75 \%)$ & 2 \\
\hline & Kerapatan tinggi (>75\%) & 1 \\
\hline
\end{tabular}


Jurnal Penelitian Saintek, Vol. 20, Nomor 1, April 2015

Tabel 2. Kriteria dan Penilaian Medan untuk Bahaya Longsor

\begin{tabular}{|c|c|c|}
\hline Variabel & Kriteria & Nilai \\
\hline \multirow[t]{5}{*}{ Lereng } & $21-55 \%$ & 5 \\
\hline & $14-20 \%$ & 4 \\
\hline & $8-13 \%$ & 3 \\
\hline & $3-7 \%$ & 2 \\
\hline & $0-2 \%$ & 1 \\
\hline \multirow[t]{5}{*}{ Tekstur } & Lempung, lempung berdebu, lempung berpasir & 5 \\
\hline & $\begin{array}{l}\text { Geluh lempung berdebu, geluh lempung berpasir, geluh } \\
\text { berlempung }\end{array}$ & 4 \\
\hline & Geluh, Debu & 3 \\
\hline & Geluh berpasir, geluh berdebu & 2 \\
\hline & Pasir, pasir bergeluh & 1 \\
\hline \multirow[t]{5}{*}{ Solum tanah } & $>100$ & 5 \\
\hline & $76-100$ & 4 \\
\hline & $51-75$ & 3 \\
\hline & $25-50$ & 2 \\
\hline & $<25$ & 1 \\
\hline \multirow[t]{5}{*}{ Permeabilitas } & $<0,5 \mathrm{~cm} / \mathrm{jam}$ & 5 \\
\hline & $0,5-2 \mathrm{~cm} / \mathrm{jam}$ & 4 \\
\hline & $2-6,25 \mathrm{~cm} / \mathrm{jam}$ & 3 \\
\hline & $6,25-12,5 \mathrm{~cm} / \mathrm{jam}$ & 2 \\
\hline & $>12,5 \mathrm{~cm} / \mathrm{jam}$ & 1 \\
\hline \multirow{5}{*}{$\begin{array}{l}\text { Singkapan } \\
\text { batuan }\end{array}$} & Sangat banyak & 5 \\
\hline & Banyak & 4 \\
\hline & Sedang & 3 \\
\hline & Sedikit & 2 \\
\hline & Tidak ada & 1 \\
\hline \multirow{5}{*}{$\begin{array}{l}\text { Penggunaan } \\
\text { lahan }\end{array}$} & Lahan kosong & 5 \\
\hline & Sawah & 4 \\
\hline & Tegalan & 3 \\
\hline & Semak belukar & 2 \\
\hline & Hutan, kebun campuran & 1 \\
\hline \multirow{5}{*}{$\begin{array}{l}\text { Kerapatan } \\
\text { vegetasi }\end{array}$} & Lahan kosong & 5 \\
\hline & Vegetasi kecil, kerapatan rendah & 4 \\
\hline & Vegetasi kecil kerapatan sedang, vegetasi besar kerapatan rendah & 3 \\
\hline & Vegetasi kecil kerapatan tinggi, vegetasi besar kerapatan sedang & 2 \\
\hline & Vegetasi besar kerapatan tinggi & 1 \\
\hline
\end{tabular}


Selanjutnya penentuan kelas bahaya dilakukan dengan penjumlahan skor total bahaya erupsi dan bahaya longsor dan dicocokkan dengan kriteria pada Tabel 3.

Teknik analisis lainnya adalah analisis SIG dan analisis keruangan. Analisis SIG dengan teknik overlay dan buffering digunakan untuk membuat satuan medan dan menyusun peta bahaya, kerawanan, kemampuan, dan risiko, sedangkan analisis keruangan secara deskriptif dilakukan untuk memperdalam pembahasan tingkat risiko dan kemampuan masyarakat dalam menghadapi bencana.

\section{HASIL DAN PEMBAHASAN}

\section{Hasil Penelitian}

Daerah penelitian meliputi seluruh wilayah Lembah Antargunungapi MerapiMerbabu yang secara administratif termasuk dalam wilayah Desa Ketep, Banyuroto, Wonolelo, Kapuhan, Krogowanan, Paten, Sengi, Krinjing, Sewukan, Jrakah, Lencoh, Klakah dan Tlogolele yang terdapat di tiga wilayah kecamatan yaitu Kecamatan Sawangan dan Dukun, Kabupaten Magelang, serta Kecamatan Selo, Kabupaten Boyolali.
Secara astronomis wilayah ini terletak pada 427800 MT hingga 440010 MT serta 9167510 MU hingga 9174300 MU pada koordinat UTM zona 49 (Gambar 1). Luas wilayah keseluruhan 4062,76ha. Secara geomorfologis daerah penelitian meliputi satuan bentuk lahan lereng bawah gunungapi, kaki gunungapi, dataran kaki gunungapi, dataran fluvial gunungapi, dataran antargunungapi, dan basin antargunungapi. Daerah penelitian dibatasi di sebelah utara oleh lereng Gunungapi Merbabu, di sebelah selatan oleh Lereng Gunungapi Merapi, di sebelah timur oleh dataran antar gunungapi Selo, dan di sebelah barat oleh dataran fluvial gunungapi Merapi-Merbabu.

Kondisi geologi daerah penelitian terdiri dari Batuan Gunungapi Merbabu, Batuan Gunungapi Merapi Muda, endapan awan panas, dan leleran puncak. Kondisi hidrologis dicirikan oleh sistem aliran sungai dengan pola aliran radial, serta keberadaan sabuk mataair pada tekuk lereng gunungapi Merapi dan Merbabu. Tipe iklim berdasarkan klasifikasi iklim Schmidt-Ferguson termasuk dalam kategori agak basah hingga basah. Penggunaan lahan meliputi sawah, kebun, permukiman, tegalan, dan semak belukar.

Tabel 3. Penentuan Kelas Bahaya Daerah Penelitian

\begin{tabular}{clc}
\hline Interval & \multicolumn{1}{c}{ Kriteria } & Kelas \\
\hline $55-65$ & Tingkat bahaya sangat tinggi & I \\
$44-54$ & Tingkat bahaya tinggi & II \\
$33-43$ & Tingkat bahaya sedang & III \\
$22-32$ & Tingkat bahaya rendah & IV \\
$11-21$ & Tingkat bahaya sangat rendah & V \\
\hline
\end{tabular}




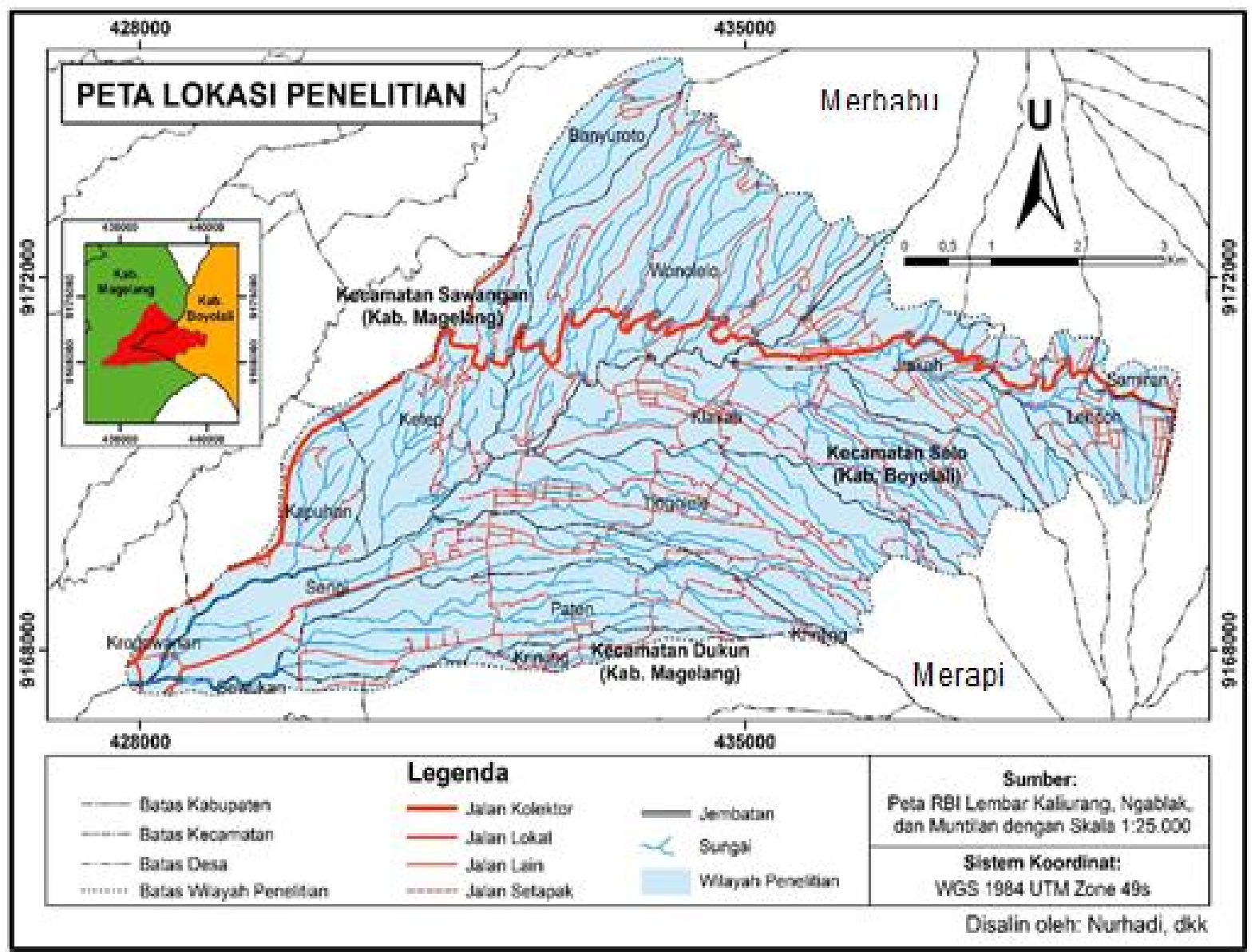

Gambar 1. Peta Administrasi Daerah Penelitian

Potensi bahaya alam pada suatu wilayah sangat berkaitan dengan karakteristik medan wilayah tersebut. Perbedaan kondisi komponen-komponen medan seperti bentuk lahan, kemiringan lereng, unit relief, litologi, jenis tanah, vegetasi, dan penggunaan lahan berpengaruh terhadap perbedaan tingkat bahaya antarwilayah. Atas dasar tersebut, dalam analisis bahaya alam dengan pendekatan geomorfologi, daerah penelitian terlebih dahulu dibagi ke dalam beberapa satuan medan sebagai satuan analisis. Berdasarkan hasil tumpangsusun peta geomorfologi, peta lereng, dan peta penggunaan lahan diperoleh 51 satuan medan pada lembah antargunungapi Merapi-Merbabu. Pada masing-masing satuan medan tersebut selanjutnya dilakukan penilaian parameter-parameter medan yang mempengaruhi bahaya erupsi gunungapi dan longsor.

Berdasarkan hasil analisis diketahui terdapat variasi tingkat bahaya di daerah penelitian baik bahaya erupsi gunungapi maupun bahaya longsor. Bahaya erupsi gunungapi terdiri dari tingkat bahaya sedang dan tingkat bahaya tinggi. Tingkat bahaya sedang meliputi sebagian besar daerah 
penelitian yaitu pada seluruh wilayah Gunungapi Merbabu dan sebagian wilayah Gunungapi Merapi. Tingkat bahaya tinggi terdapat di sebagian wilayah Gunungapi Merapi (Gambar 2).

Tingkat bahaya tinggi hanya dijumpai di sebagian wilayah Gunungapi Merapi yang disebabkan aktivitas Merapi sebagai vulkan yang aktif sehingga menimbulkan ancaman bahaya erupsi. Adapun Gunungapi Merbabu termasuk vulkan yang tidak aktif sehingga pada saat ini tidak menimbulkan bahaya erupsi. Oleh karena kondisi tersebut maka daerah penelitian yang terletak diantara dua gunungapi tidak seluruhnya menghadapi potensi bahaya tinggi. Pada wilayah Gunungapi Merbabu hanya terdapat tingkat bahaya erupsi sedang karena jarak dari pusat erupsi Gunungapi Merapi relatif jauh, serta pengaruh relief yang berperan dalam menghambat aliran material erupsi dari Gunungapi Merapi.

Faktor-faktor yang mempengaruhi tingkat bahaya erupsi antara lain bentuklahan, lereng, unit relief, jarak dari kepundan, jarak dari alur sungai, penggunaan lahan, kerapatan alur sungai, kerapatan vegetasi, dan fasies gunungapi. Di antara faktor-faktor tersebut,

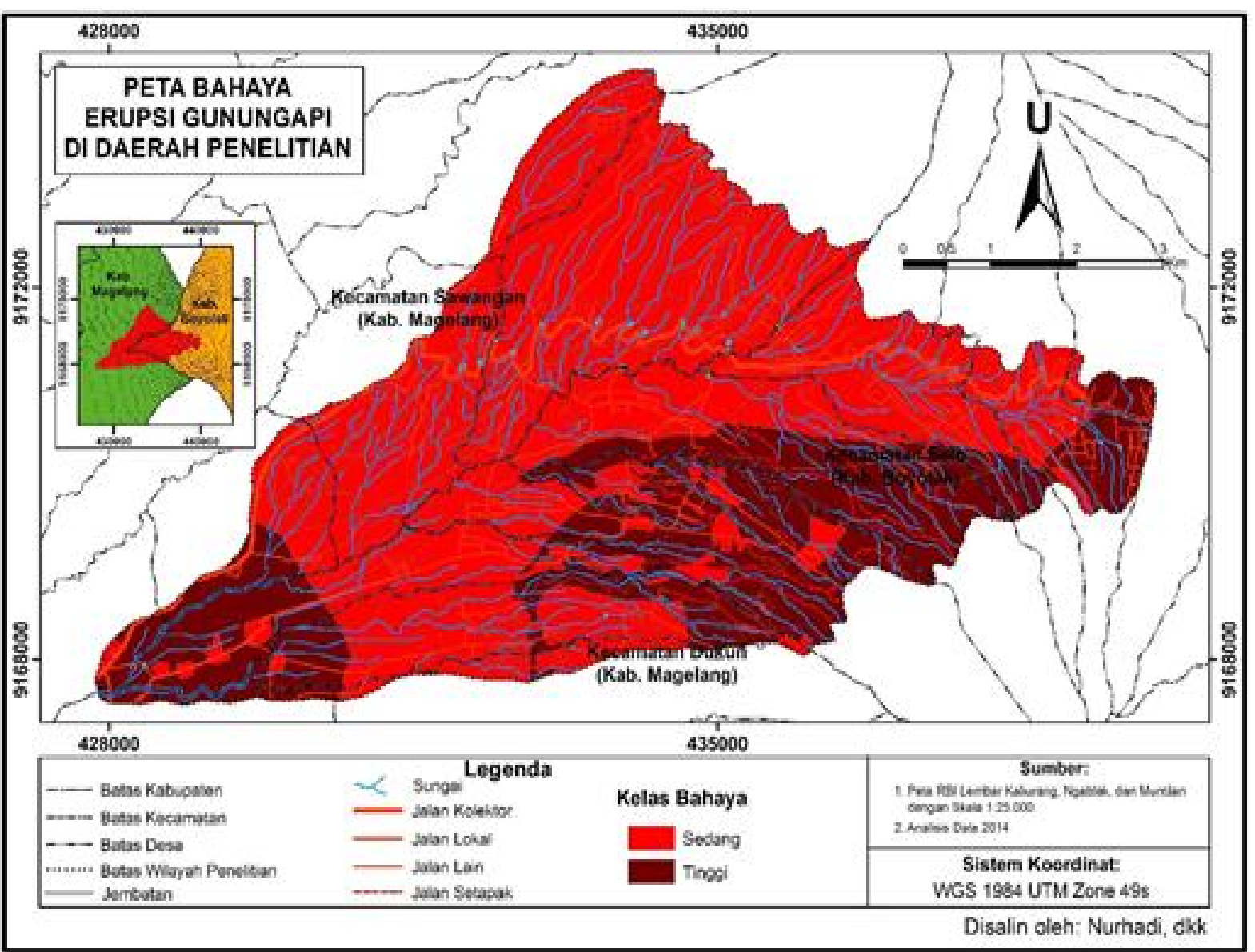

Gambar 2. Peta Tingkat Bahaya Erupsi Lembah Antargunungapi Merapi-Merbabu 
faktor utama yang berpengaruh besar dalam menentukan tingkat bahaya erupsi di daerah penelitian adalah jarak dari kepundan, jarak dari alur sungai, kemiringan lereng, dan unit relief. Wilayah yang berdekatan dengan kepundan sebagai pusat erupsi maupun alur sungai sebagai jalur aliran material erupsi berpotensi untuk terkena berbagai jenis material produk erupsi dengan berbagai intensitas, sehingga tingkat bahayanya semakin tinggi. Kemiringan lereng semakin tinggi mempengaruhi laju maerial hasil erupsi menjadi semakin cepat sehingga meningkatkan bahaya. Unit relief berkaitan dengan lereng. Pada unit relief bergunung kemiringan lereng semakin tinggi, yang selanjutnya mempengaruhi laju maerial hasil erupsi sebagaimana dijelaskan di atas. Namun demikian, relief dengan orientasi lereng yang berlawanan seperti pada Gunungapi Merbabu terhadap Gunungapi
Merapi justru berperan dalam mengurangi bahaya akibat aliran material hasil erupsi tersebut. Salah satu bentuk pengaruh faktor jarak dari alur sungai dan unit relief terhadap dampak lingkungan yang terjadi pasca erupsi tahun 2010 ditunjukkan oleh Gambar 3.

Bahaya longsor di daerah penelitian bervariasi antara tingkat sangat rendah, rendah, hingga sedang. Tingkat bahaya sedang mencakup sebagian besar daerah penelitian yaitu pada seluruh wilayah lereng Gunungapi Merbabu serta sebagian kecil wilayah Gunungapi Merapi. Tingkat bahaya rendah terdapat pada sebagian wilayah lereng Gunungapi Merapi dan kaki Gunungapi Merapi di sekitar lembah Sungai Pabelan. Adapun tingkat bahaya sangat rendah meliputi wilayah yang sangat sedikit pada sebagian kaki Gunungapi Merapi (Gambar 4).

Tingkat bahaya longsor sedang banyak terdapat pada wilayah Gunungapi Merbabu

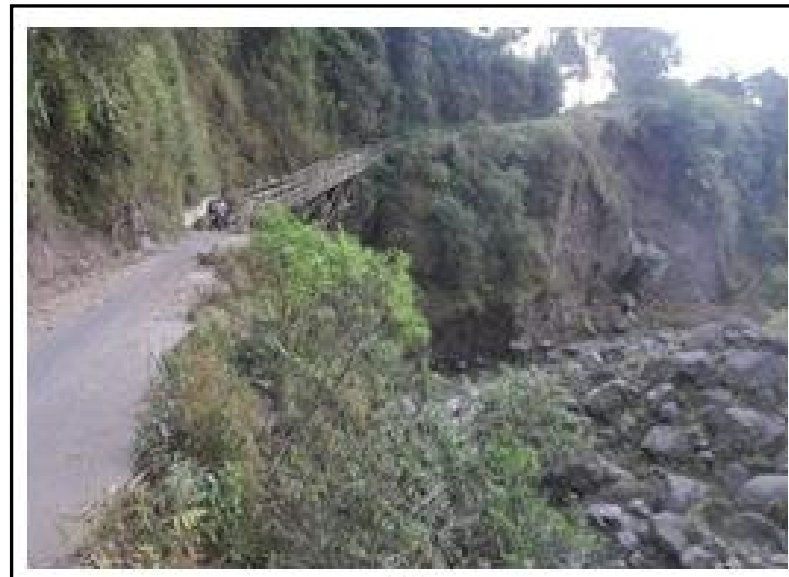

A

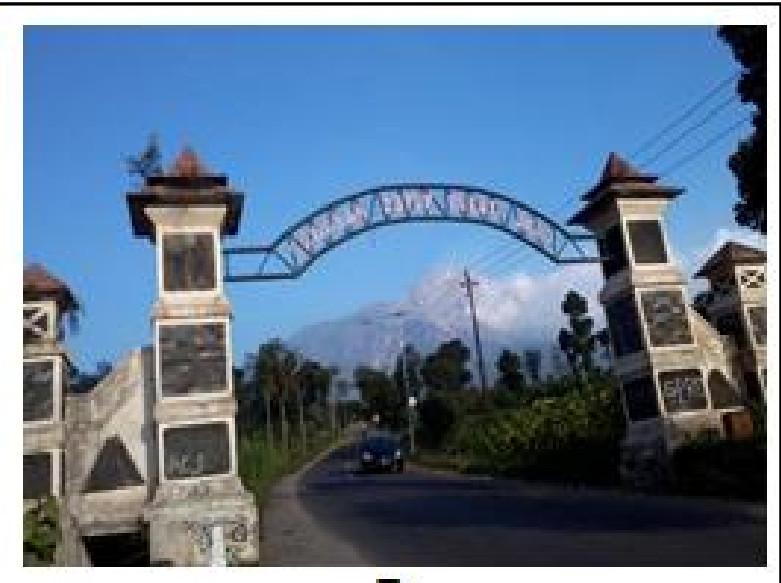

B

Gambar 3. A = Kerusakan Infrastruktur Jalan oleh Aliran Lahar di Sempadan Sungai Pabelan

Desa Jrakah, Kecamatan Selo. B = Wilayah Sekitar Perbatasan Kecamatan SeloKecamatan Sawangan dengan Tingkat Kerusakan Rendah oleh karena Pengaruh Faktor Relief Kaki Gunungapi Merbabu 


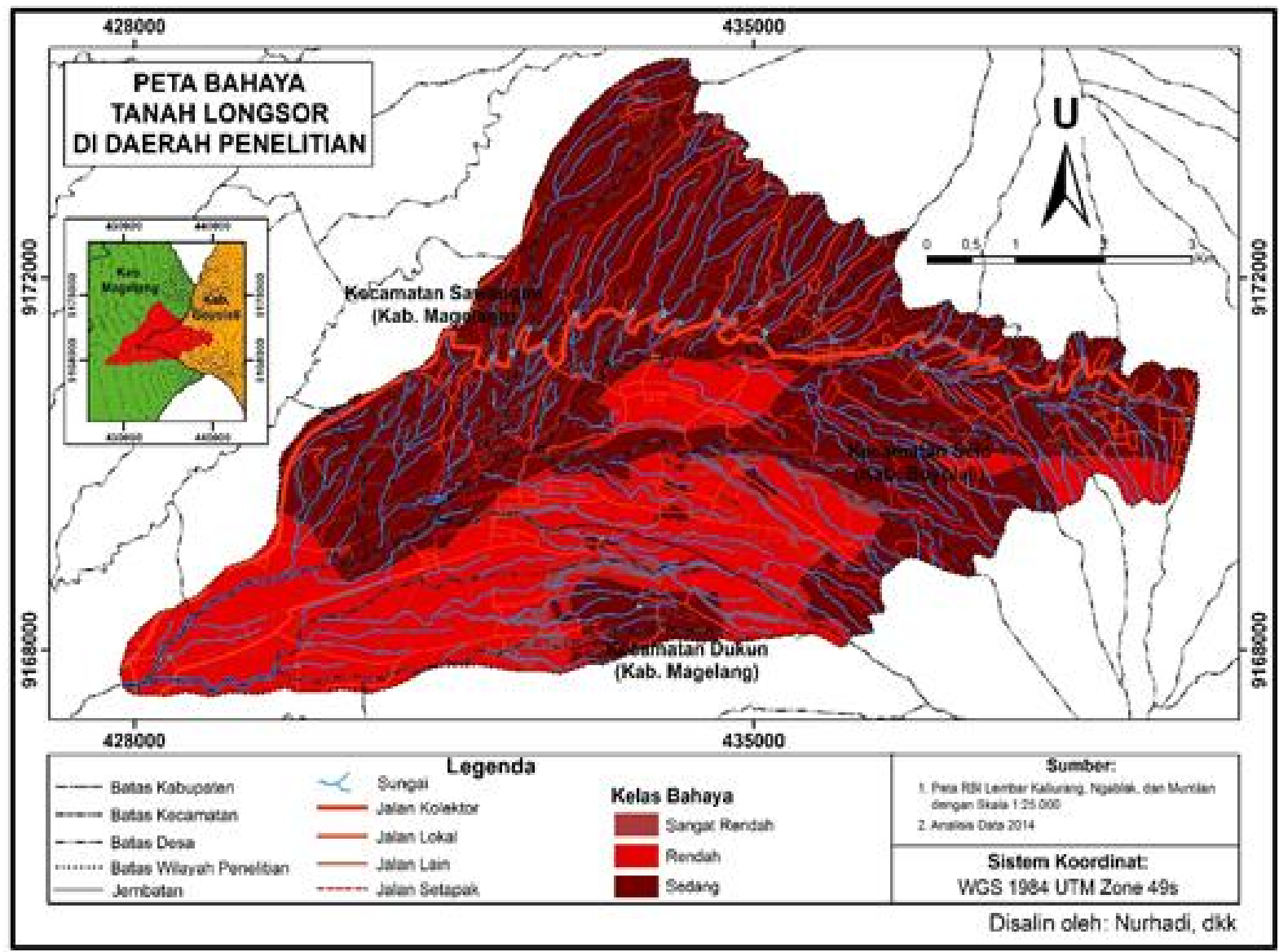

Gambar 4. Peta Tingkat Bahaya Longsor Lembah Antargunungapi Merapi-Merbabu

disebabkan oleh karakteristik Gunungapi Merbabu sendiri sebagai vulkan yang tidak aktif. Pada tipe vulkan tidak aktif pembaruan material oleh hasil aktivitas vulkanik tidak berlangsung lagi. Sementara itu pengaruh proses eksogen dalam waktu lama telah mendorong terjadinya pelapukan secara intensif. Wilayah yang telah banyak mengalami pelapukan memiliki solum tanah tebal dengan tekstur lempung yang sangat rentan terhadap proses gerakan massa, salah satunya dalam bentuk longsor. Adapun pada wilayah Gunungapi Merapi dengan usia pembentukan lebih muda daripada Gunungapi Merbabu serta masih terjadi pembaharuan material vulkanik, tingkat bahaya longsor relatif kecil karena material vulkanik yang dihasilkan relatif belum padu.

Faktor-faktor yang mempengaruhi tingkat bahaya longsor antara lain kemiringan lereng, tekstur tanah, kedalaman solum tanah, singkapan batuan, penggunaan lahan, dan kerapatan vegetasi. Berdasarkan hasil analisis, faktor yang paling berpengaruh dalam menentukan tingkat bahaya longsor di daerah penelitian adalah kemiringan lereng, tekstur tanah, ketebalan solum tanah, dan penggunaan lahan. Kemiringan lereng yang semakin besar menjadi faktor pemacu longsor sehingga meningkatkan bahaya 
longsor. Faktor pemotongan lereng untuk pelebaran jalan pada jalur jalan penghubung Ketep-Selo tanpa disertai dengan bangunan penguat lereng juga meningkatkan bahaya longsor, bahkan selama musim penghujan pada jalur jalan ini banyak terjadi longsor. Tekstur tanah yang telah berkembang semakin halus ditambah dengan solum tanah tebal menyebabkan berkurangnya stabilitas tanah pada lereng dan menimbulkan bidang gelincir sehingga memacu longsor. Penggunaan lahan pertanian tanpa disertai vegetasi penguat lereng juga berpengaruh terhadap longsor dan erosi. Gambar 5 menunjukkan salah satu bagian wilayah lereng Gunungapi Merbabu yang sering mengalami longsor dibawah pengaruh kemiringan lereng tinggi dan penutup lahan tanpa vegetasi penguat lereng.

\section{Pembahasan}

Berdasarkan hasil penelitian diketahui tingkat bahaya erupsi gunungapi tinggi pada lembah antargunungapi MerapiMerbabu terdapat di bagian wilayah Gunungapi Merapi. Hal ini tidak terlepas dari karakteristik Gunungapi Merapi sebagai vulkan aktif. Selanjutnya faktor utama yang mempengaruhi tingkat bahaya erupsi pada suatu wilayah adalah jarak dari kepundan, jarak dari alur sungai, kemiringan lereng, dan unit relief. Jarak dari kepundan sangat

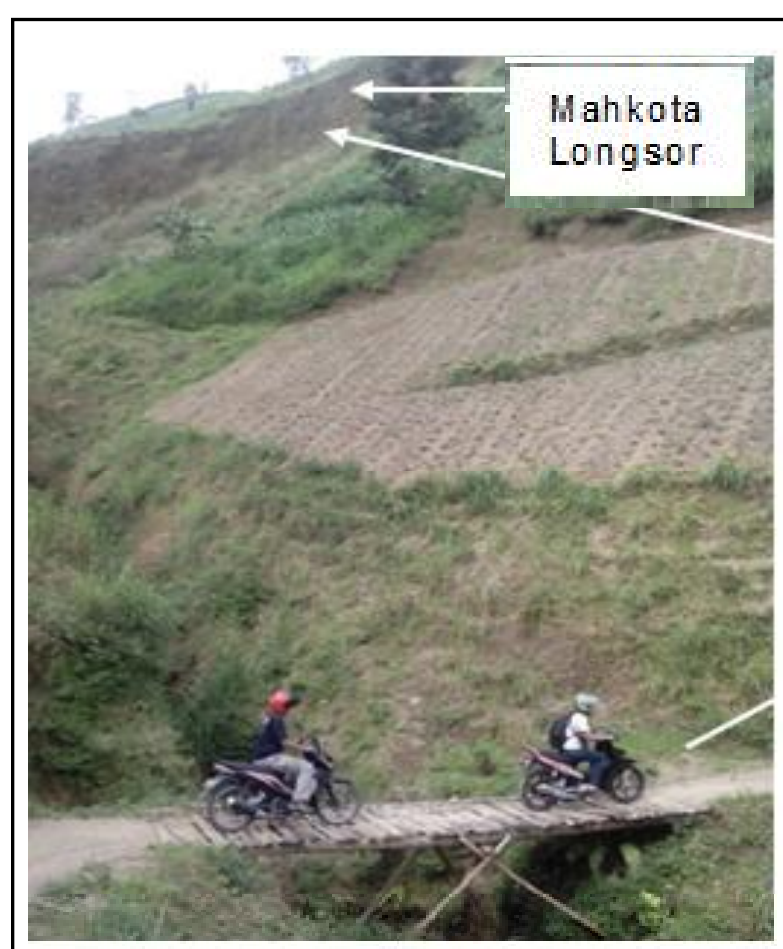

A

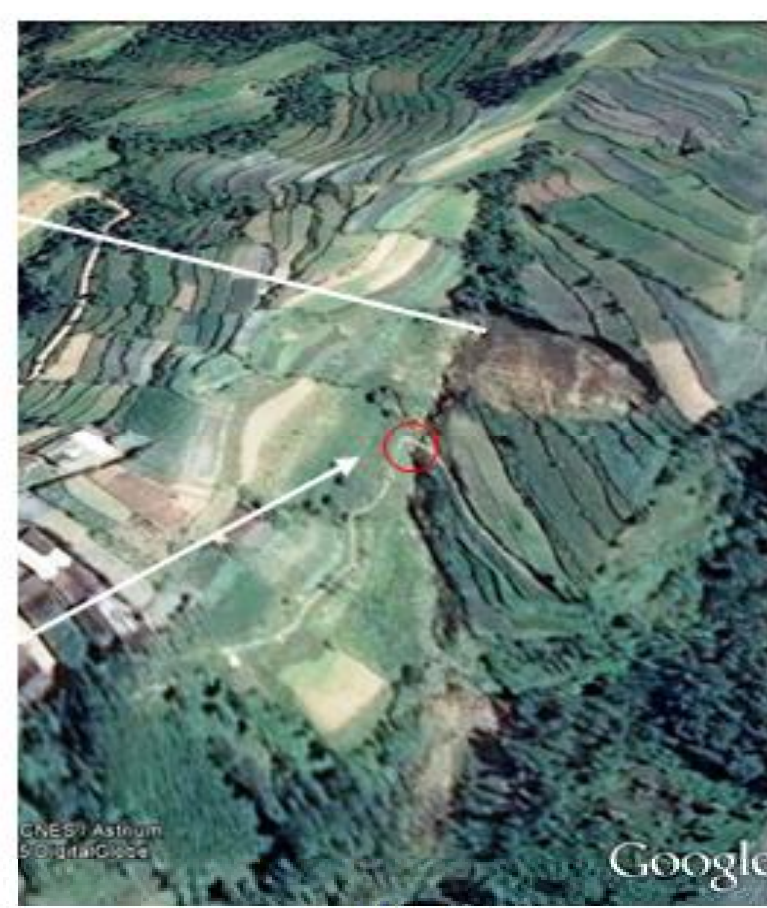

B

Gambar 5. Bekas Longsoran pada Bagian Wilayah Lereng Gunungapi Merbabu di Desa Wonolelo. A: Kenampakan Longsor di Lapangan, B: Kenampakan pada Citra Google Earth 
menentukan tingkat bahaya erupsi karena berkaitan dengan material hasil erupsi baik yang bersifat bahaya primer maupun sekunder. Gunungapi Merapi memiliki bahaya primer dan sekunder yang cukup banyak, bahaya primer berupa lava, awan panas, gas vulkanik, abu vulkanik, lahar letusan, dan lontaran piroklastik (Sutikno, 2007). Dinamika aktivitas Gunungapi Merapi terbentuk oleh karena magma agak kental yang berasal dari dapur magma dengan kedalaman menengah terdorong ke atas cukup kuat. Letusan yang cenderung eksplosif dan menghasilkan berbagai jenis bahaya tidak terlepas dari karakteristik magma termasuk asimilasinya dengan berbagai jenis batuan di sekitar wilayah Gunungapi Merapi (Sutikno, 2007; Borisova et al., 2013).

Jarak yang relatif dekat dari pusat erupsi Gunungapi Merapi memungkinkan suatu wilayah terdampak berbagai jenis bahaya. Potensi bahaya akan semakin besar apabila didukung oleh kemiringan lereng dan konfigurasi relief yang memungkinkan terjadinya aliran material hasil erupsi ke wilayah tersebut. Wilayah pada jarak 1-6 km menghadapi bahaya akibat aliran lava, aliran debu dan gas, material jatuhan piroklastik, aliran piroklastik yang terus meluncur hingga jarak $9 \mathrm{~km}$, serta aliran lahar yang juga terus terangkut hingga mencapai jarak $20 \mathrm{~km}$ dari pusat erupsi. Semakin menjauhi pusat erupsi jenis bahaya semakin berkurang tergantung pada kemampuan menjangkau wilayah jauh yang umumnya berkaitan dengan agen geomorfik sebagai pengangkut (Verstappen, 2013; Sutikno, 2007; Marfai, 2012; Bronto, 2006).

Jarak dari alur sungai juga merupakan faktor yang sangat berpengaruh dalam menentukan tingkat bahaya erupsi di daerah penelitian. Hal ini disebabkan oleh karena pada alur-alur sungai tersebut terjadi transport material hasil erupsi, terutama material volkaniklastik pasca erupsi. Berdasarkan hasil observasi lapangan dalam penelitian ini diketahui terdapat beberapa bentuk kerusakan lingkungan di sekitar alur sungai. Sungai Pabelan sebagai sungai utama yang terdapat pada lembah antar gunungapi Merapi-Merbabu, pada erupsi tahun 2010 mengalami kejadian lahar terbanyak setelah Kali Putih. Banyaknya material dan seringnya kejadian lahar menyebabkan kerusakan pada lingkungan di sekitar alur sungai, termasuk diantaranya bangunan pengendali sedimen (Hadmoko, 2014). Di beberapa daerah juga terjadi kerusakan permukiman akibat banjir lahar yang dipengaruhi oleh jarak permukiman dari alur sungai dan tinggi endapan banjir lahar (Kumalawati, 2014). Di sekitar alur Sungai Pabelan luapan banjir lahar banyak terjadi pada wilayah dengan lereng kurang dari 100, indeks posisi topografi berupa lembah, plan curvature dan profile curvature datar dan cekung (Nugraha, 2014). 
Tingkat bahaya longsor terdapat pada wilayah Gunungapi Merbabu. Hal ini disebabkan oleh karakteristik Gunungapi Merbabu sebagai vulkan yang tidak aktif, yang tidak banyak mengalami peremajaan material hasil erupsi namun disisi lain telah banyak mengalami pelapukan akibat pengaruh iklim yang kuat. Faktor utama yang menentukan tingkat bahaya longsor di daerah penelitian adalah kemiringan lereng, tekstur tanah, ketebalan solum tanah, dan penggunaan lahan. Ketebalan lapukan batuan yang menunjukkan volume material besar berperan dalam meningkatkan gaya berat yang apabila terjadi pada lereng yang miring sampai curam akan menyebabkan ketidakstabilan lereng. Menurut Hardjono (2013) potensi bahaya longsor tinggi umumnya memiliki karakteristik kemiringan lereng yang terjal, pelapukan batuan sedang, adanya pemusatan air tanah, adanya pengikisan tebing sungai, kedalaman airtanah dalam, adanya penggalian tebing yang dilakukan oleh penduduk, dan penggunaan lahan tegalan. Pada daerah penelitian khususnya di wilayah Gunungapi Merbabu, peristiwa longsor lebih banyak terjadi pada penggunaan lahan tegalan daripada kebun campuran, semak belukar, maupun permukiman. Adapun penggalian tebing berupa pemotongan lereng untuk pengembangan jalur transportasi juga berperan terhadap peristiwa longsor yang terjadi.

\section{KESIMPULAN}

Analisis bahaya erupsi gunungapi dan longsor dengan pendekatan geomorfologi pada lembah antar gunungapi MerapiMerbabu menunjukkan variasi tingkatbahaya erupsi terdiri dari tingkat bahaya sedang dan tingkat bahaya tinggi. Tingkat bahaya sedang meliputi sebagian besar daerah penelitian yaitu pada seluruh wilayah Gunungapi Merbabu dan sebagian wilayah Gunungapi Merapi. Tingkat bahaya erupsi dipengaruhi oleh faktor bentuklahan, lereng, unit relief, jarak dari kepundan, jarak dari alur sungai, penggunaan lahan, kerapatan alur sungai, kerapatan vegetasi, dan fasies gunungapi. Faktor utama yang mempengaruhi tingkat bahaya erupsi di daerah penelitian adalah jarak dari kepundan, jarak dari alur sungai, kemiringan lereng, dan unit relief.

\section{DAFTAR PUSTAKA}

Borisova, A.Y., Martel, C., Gouy, S., Pratomo, I., Sumarti, S., Toutain, J.P., Bindeman, I.A., Metaxian, J.P., Surono. 2013. Highly Explosive 2010 Merapi Eruption: Evidence for Shallow-Level Crustal Assimilation and Hybrid Fluid. Journal of Volcanology and Geothermal Research. Special Volume on the 2010 Merapi Eruption Version, 1: 1-54

Eiser, J.R., Bostrom, A., Burton, I., Johnston, D.M., McClure, J., Paton, D., Pligt, J.V.D., White, M.P. 2012. Risk Interpretation and Action: A Conceptual Framework for Responses to Natural Hazards. International 
Journal of Disaster Risk Reduction, 1 (2012): 5-16.

Flanagan, B.E., Gregory, E.W., Halisey, E.J., Heitgerd, J.L., Lewis, B. 2011. A Social Vulnerability Index for Disaster Management. Journal of Homeland Security and Emergency Management, 8 (1): 1-22.

Hadmoko, D.S., Nugraha, H., Suryani, T., Marfai, M.A., Widiyanto., Nurzeha, R., Mutaqin, B.W., Dipayana, G.A., Yulianto, F., Susmayadi, I.M., Khomarudin, M.R. 2014. Kerusakan Bangunan Pengendali Sedimen di Kali Pabelan. Prosiding Pertemuan Ilmiah Tahunan XVII Ikatan Geograf Indonesia. Yogyakarta 15-17 November 2014.

Hardjono, I. 2013. Pemintakatan Bahaya Longsor Lahan di Kecamatan Manyaran Kabupaten Wonogiri Propinsi Jawa Tengah. Forum Geografi, 22 (2): 113128.

Kaku, K. and Held, A. 2013. Sentinel Asia: Space-based Disaster management Support System in the Asia-Pacific Region. International Journal of Disaster Risk Reduction, 6 (2013): 1-17.

Kumalawati, R., Sartohadi, J., Kartika, N.Y., Rijal, S.S. 2014. Evaluasi Kerusakan Permukiman akibat Banjir Lahar Pasca Erupsi Gunungapi Merapi 2010 di Kabupaten Magelang. Prosiding Pertemuan Ilmiah Tahunan XVII Ikatan Geograf Indonesia. Yogyakarta 15-17 November 2014.

Lavigne, F. 2010. Ulasan Publikasi. dalam: Sunarto.. Marfai. M.A.. dan Mardiatno. D (ed). Penaksiran Multirisiko Bencana di Wilayah Parangtritis: Suatu Analisis Serbacakup untuk
Membangun Kepedulian Masyarakat terhadap Berbagai Kejadian Bencana. Yogyakarta: BPFG

Marfai, M.A., Cahyadi, A., Hadmoko, D.S., Sekaranom, A.B. 2012. Sejarah Letusan Gunung Merapi Berdasarkan Fasies Gunungapi di Daerah Aliran Sungai Bedog, Daerah Istimewa Yogyakarta. Riset Geologi dan Pertambangan, 22 (2): 73-79.

Nugraha, H., Hadmoko, D.S., Marfai, M.A., Mutaqin, B.W., Yulianto, F., Susmayadi, I.M., Dipayana, G.A., Khomarudin, M.R. 2014. Karakteristik Geomorfometri Lokasi Luapan Lahar Kali Pabelan, Magelang, Jawa Tengah. Prosiding Pertemuan Ilmiah Tahunan XVII Ikatan Geografi Indonesia. Yogyakarta 15-17 November 2014.

Sudibyakto. 2007. Potensi Bencana Alam Dan Kesiapan Masyarakat Menghadapi Bencana (preparedness for Vulnerable Communities). Pengantar Diskusi Bulanan. Pusat Studi Pedesaan dan Kawasan (PSPK) Universitas Gadjah Mada. 4 Oktober 2007.

Sudradjat, A., Syafei, I., dan Paripurno, E.T. 2010. The Characteristics of Lahar in Merapi Volcano, Central Java as the Indicator of the Explosive during Holocene. Jurnal Geologi Indonesia, 6 (2): 69-74.

Sutikno. 2007. "Mengakrabi Bumi. Bagaimana?". Makalah Motivation on Disaster. Joint Program: UGM-Fakultas Geografi \& DMII. Yogyakarta.

Undang-Undang Republik Indonesia Nomor 24 Tahun 2007 tentang Penanggulangan Bencana, LNRI Tahun 2007 Nomor 66, TLNRI Nomor 4723. 
Van Bemmelen, R.W. 1970. The Geology of Indonesia: General Geology of Indonesia and Adjacent Archipelagoes 1949. $2^{\text {nd }}$ ed., vol. IA. Martinus Nijhoff, The Hague, Vol. 1, 732.Verstappen, H. 2013. Garis Besar Geomorfologi Indonesia, Terjemahan oleh Sutikno. Yogyakarta: Gadjah Mada University Press.

Van Padang, M.N. 1983. History of the Volcanology in the former Netherlands
East Indies. Scripta Geol, 71 (1983): $1-81$.

Verstappen, H. 2000. Outline of the Geomorphology of Indonesia, a Case Study on Tropical Geomorphology of a Tectogene Region. Enschede: International Institute for Aerospace Surveys and Earth Sciences. 